\title{
Pathophysiology of Noise Induced Hearing Loss
}

\author{
Chan Joo Yang, Jong Woo Chung \\ Department of Otolaryngology, Asan Medical Center, University of Ulsan College of Medicine, Seoul, Korea
}

\author{
소음성 난청의 기전 \\ 양 찬 주·정 종 우
}

울산대학교 의과대학 서울아산병원 이비인후과학교실

\begin{abstract}
Hearing loss due to the noise exposure has become a major cause of irreversible hearing disturbance and deafness. Hearing threshold shift after noise exposure can be temporary or permanent. Noise-induced hearing loss can be caused by a one-time exposure to an intense "impulse" sound or by continuous exposure to loud sounds over an extended period of time. The major mechanisms of noise-induced hearing loss are physical damage in organ of Corti, decreased blood flow causing the hypoxia of the inner ear, oxidative stress of reactive oxygen species (ROS), and neural degeneration in synaptic terminals of cochlear nerve fibers and spiral ganglion cells. Recent studies revealed that the neural degeneration was also observed in temporary hearing threshold shift and cumulative damage in transient threshold shift is likely to eventually lead to permanent hearing loss. This suggests that the repetitive transient noise-induced hearing loss can cause age-related hearing loss.
\end{abstract}

Key Words: Noise-induced hearing loss, Mechanism, Nerve degeneration.

Received: January 31, 2016 / Accepted: March 10, 2016

Correspondence: Jong Woo Chung, Department of Otolaryngology, Asan Medical Center, University of Ulsan College of Medicine, 88 Olympic-ro 43-gil, Songpa-gu, Seoul 05505, Korea

Tel: +82-2-3010-3710 / Fax: +82-2-489-2773 / E-mail: gfinderjw@gmail.com

\section{INTRODUCTION}

현대 사회에서 소음에 의한 청력의 손상은 회복되지 않는 청 력 손실 및 난청의 가장 큰 원인이 되고 있다. 사회의 발전과 더 불어 귀와 관련된 기존의 염증성 질환들은 점차 줄어드는 추 세이나 직업과 관련된 과도한 소음 피폭이나 군대 내에서의 총 기류나 폭발물에 의한 청각의 손상은 오히려 늘어나는 추세이 다. 또한 오락 활동이 늘어나면서 각종 콘서트장이나 업소에서 청각에 파괴적인 영향을 끼칠 수 있는 큰 음향에 노출되는 일 이 잦아지고 MP3와 같은 음향기기를 과도하게 사용하는 인구 가 늘면서 청력의 손상은 사회적인 문제가 되어가고 있다. 이런 음향 외상은 폭발음 등과 같은 강력한 음자극에 단시간 노출되 었을 때 부분적 또는 완전한 감각신경성 청력 손실을 초래한 다. 소음 노출 후 휴식기간을 가지면 청력이 회복되는 가역성 청력손실을 일시적 역치변동(temporary threshold shift, TTS), 소음에 노출된 후 회복되지 않는 비가역적인 감각신경성 청력 손실을 영구적 역치변동(permanent threshold shift, PTS)이라
고 하며 이를 소음성 난청이라고 말하기도 한다.

소음성 난청 환자의 50 70\%는 만성적인 귀울림 증상인 만 성 이명을 동반하는 것으로 알려져 있으며 이들 환자의 난청과 이명은 개개인의 의사소통 고립, 직장 및 가정에서의 업무 효율 저하, 직장에서의 조기 은퇴를 가져와 국가적으로도 큰 사회경 제적인 손실로 연결되고 있다(Axelsson \& Sandh, 1985). 우리 나라 남자들에게 특히 소음에 의해 발생하는 것으로 여겨지는 고음성 난청이 40 대부터 나타나기 시작하여 나이가 들수록 심 한 난청으로 발전한다(Ahn et al., 2005). 이는 나이가 듦에 따 라 생기는 노인성난청과 상등작용을 가지게 되어 직업을 가지고 일하는 젊은 산업 인구뿐 아니라 노년 삶에 상당한 장애를 초래 하게 된다. 실험적인 결과를 참고해 보면 젊었을 때 소음에 노출 되면 그 당시에는 큰 불편이 없고 회복된다고 하여도 나이가 들 면서 더 빨리 외유모세포의 기능이상이 발생하게 된다. 또한 나 이가 들어서 소음에 노출되면 청신경절의 신경세포가 더 빨리 손상을 입게 된다(Kujawa \& Liberman, 2006). 그러므로 소음 성 난청은 고령화 사회의 커다란 질병으로 대두하게 될 것이다. 


\section{REVIEW}

\section{소음성 난청의 발생기전}

소음성 난청에 관한 연구는 이미 1800년대부터 시작하여 발 생기전과 손상부위, 소음종류에 따른 다양한 손상이 연구되었 다. 그러나 형태적인 연구에 국한되어 있다가 1980년부터 다양 한 발생기전이 발표되었다. 소음성난청의 주요한 손상기전은 첫 째, 물리적 손상에 의한 내이 코티기관의 변화이다. 주로 감각 유모세포들이 비틀어지고 기저막에서 떨어지며 코티기관 자체 의 고유한 구조가 망가진다(Hawkins et al., 1976; Mulroy et al., 1998; Spoendlin, 1971). 두번째 손상기전은 혈류량 저하와 저산소증이다. 내이로 공급되는 혈류량이 소음에 의해 감소하 며, 2차적인 변화로 내이의 저산소증이 발생한다(Chung et al., 2004; Lamm \& Arnold, 1996). 저산소증은 반드시 혈류량 저 하와 연관이 있는 것은 아니며, 조직의 산소소모량이 증가하여 발생하는 기전도 제시되었다(Lamm \& Arnold, 1996; Lamm et al., 1998). 세 번째 기전은 가장 중요하며, 가장 많은 연구가 이루어진 부분으로 활성산소유리기(Reactive oxygen species, $\mathrm{ROS})$ 의 발생에 의한 조직의 손상기전이다. 이 기전은 ROS발생 의 증명(Ohlemiller et al., 1999; Yamane et al., 1995) 과 그 대 사산물의 증가(Ohinata et al., 2000), 항산화제 사용에 의한 난 청의 예방(Kopke et al., 2002; Ohinata et al., 2000; Yamasoba et al., 1998) 등의 연구에 의해 확실히 뒷받침되었다. 또한 활성 질소유리기(Reactive nitrogen species, RNS)도 소음에 의해 내 이에서 증가하는 것으로 보고되었다. ROS에 의한 손상기전의 마지막 단계는 대개 apoptosis로 귀결되며 이전에는 apoptosis 가 다른 기전으로 생각했으나 최근에는 ROS $\rightarrow$ apoptosis로 이 어지는 하나의 기전으로 생각되고 있다. 네번째 기전은 내유모 세포와 신경말단부위에서 발생하는 흥분독성(excitotoxicity) 으로 소음에 의해 신경말단부위의 glutamate의 증가에 의해 구심성신경이 손상되어 난청이 발생한다는 기전이다(Janssen et al., 1991; Le Prell et al., 2004; Puel et al., 1991; Puel et al., 1994). 다섯번째 기전은 중추신경계로부터의 원심성 조절기전 의 변화이다. 이 기전에 대해서는 아직 많은 연구가 이루어지지 않았다. 또 하나 중요한 기전으로 내이세포의 calcium 항상성 (homeostasis)의 변화에 의한 것이 있다. 그러나 이는 위에 열 거한 기전에 의한 2 차적인 변화를 의미하는 것이다(Le Prell et al., 2007). 그밖에 여러 가지 기전들이 각자의 증거를 가지고 무수히 보고되었다.

\section{소음성 난청의 예방 및 치료}

이런 기전을 예방하는 방법을 이용하여 소음성 난청의 예방, 치료기법이 발전하였는데 물리적 손상에 대해서는 차폐기를
이용하여 소리의 물리적 에너지를 줄이는 방법, 혈류량 저하나 저산소증에 대해서는 혈류량을 증가시키고 내이의 환경을 조직 이 더 잘 버틸 수 있는 환경으로 바꿔주는 방법을 이용한다. 주 로 steroid나 neurotrophin, carbogen, non-steroidal anti-inflammatroy durg등을 사용하며 예방이 가능하다(Lamm \& Arnold, 1998; Lamm et al., 1998; Le Prell et al., 2007). 또한 $\mathrm{ROS}$ 나 RNS의 증가에 대해서는 우리 몸에 원래 존재하고 있 는 내인성 항산화제인 glutathione을 공급해주는 방법과 다른 항산화 효소를 공급하는 방법, 또는 체내에서 생성을 활발하게 만들어주는 방법들을 사용하여 예방과 효과를 가진다(Kil et al., 2007; Lynch et al., 2004; Yamasoba et al., 2005). 그리고 최종단계인 apoptosis를 막는 anti-apoptotic agent를 이용하 여 예방하는 방법도 보고되고 있다(Ahn et al., 2005; Wang et al., 2007). 흥분독성에 대해서는 RNS Scavenger를 이용하는 방법을 사용하고, glutamate를 감소시키는 또는 효과를 억제하 는 약제를 사용할 수 있다.

\section{소음성 난청에서 내이 청신경계의 변화}

소음에 의해 Corti 기관의 해부학적 및 생리학적 구조의 기 계적 손상이 발생하고 이차적으로 나선신경절 세포의 손실이 발생하는 것을 이차 신경 변성, 유모세포의 손상 없이 나선신경 절 세포의 손상이 비가역적으로 발생하는 것을 일차 신경 변성 이라 한다. 소음성 난청에 관한 최근의 연구에서 소음에 의한 일시적 또는 영구적인 청력 역치의 변동은 일차 신경의 변성과 관계되어 있다고 밝히고 있다. 즉, 소음에 의한 신경의 변성은 소음 노출 후 즉시 발생하고 이것이 수년간 진행을 하는 것이 다. 소음성 일차 신경 변성은 내유모세포의 말단부위와 나선신 경절 세포에 발생하며 이는 청력 역치의 회복이나 내, 외유모세 포의 손상과 상관없이 발생할 수 있다(Kujawa \& Liberman, 2006). 소음자극에 의해 일과성 청력 역치변동이 발생하고 다 시 청력이 정상으로 회복된다고 하여도 시냅스와 관련된 신경 의 손상은 발생할 수 있다는 보고가 있었다. 즉, 청성뇌간반응 및 변조이음향반사에서의 역치가 정상으로 회복되고 감각유모 세포의 손상은 발견되지 않았지만 내유모세포 말단의 신경섬 유의 변화가 관찰된 것이다(Kujawa \& Liberman, 2009; Seo et al., 2013). 이러한 손상은 반복적인 소음 자극에 의해 더 항 진되어 결국 영구적 청력 역치변동까지 발생할 수도 있다고 여 겨진다.

일과성 역치변동의 경우 유모세포의 손실이 관찰되지는 않지 만 시냅스에서 신경 말단의 glutamate 흥분독성(excitotoxicity) 에 의한 와우신경말단의 부종을 소음 노출 후 24 시간 내에 전 자현미경을 통해 관찰할 수 있다(Liberman \& Kiang, 1984). 소리 자극에 의한 이러한 흥분독성은 glutamate 길항제로 억 
제될 수 있고 역으로 소리 자극이 없이도 glutamate 항진제를 이 용하여 비슷한 신경말단의 부종을 유발할 수도 있다(Ruel et al., 2007). 일과성 청력변동에서 이러한 glutamate 시냅스의 구조적 인 변화는 청각의 회복과 함께 회복되는 경향을 보이며, 이것은 시냅스 구조물의 회복과 재생에 의한 것으로 생각되고 있다.

\section{일과성 소음성 난청과 노화성 난청과의 연관성 추정}

소음 노출 후에 청력 역치가 호전되는 일과성 소음성 난청의 경우 내이의 물리적인 감각기관들과 신경 구조의 손상이 회복 되는 것이며, 청력에 영구적인 영향은 없는 것으로 인식되어 왔 다. 하지만 앞서 언급하였듯이 여러 연구에서 소음 유발 손상 이 기존의 역치 검사에서 밝혀진 것보다 더 넓은 범위에서 진행 되는 결과들을 유발함을 제시하였다. 그리고 이러한 일과성 소 음성 난청으로 인한 손상이 누적된다면 결국 영구적인 청력 역 치의 저하로 이어질 가능성이 있으며, 이는 일과성 소음성 난청 의 경우 장기적인 악영향이 없다는 기존의 연구 결과들을 뒤집 는 것이다. 이는 반복적인 일과성 소음성 난청이 노화성 난청 의 원인이 될 수 있다는 점을 시사한다.

중심 단어 : 소음성 난청·기전·신경 변성.

\section{REFERENCES}

Ahn, J. H., Kang, H. H., Kim, Y. J., \& Chung, J. W. (2005). Anti-apoptotic role of retinoic acid in the inner ear of noise-exposed mice. Biochemical and Biophysical Research Communications, 335(2), 485-490.

Axelsson, A. \& Sandh, A. (1985). Tinnitus in noise-induced hearing loss. British Journal of Audiology, 19, 271-276.

Chung, J. W., Kang, H. H., Shin, J. E., \& Kim, J. U. (2004). Accumulation of hypoxia-inducible factor-1alpha in mouse inner ear by noise stimulation. Neuroreport, 15, 2353-2356.

Hawkins, J. E., Johnsson, L. G., Stebbins, W. C., Moody, D. B., \& Coombs, S. L. (1976). Hearing loss and cochlear pathology in monkeys after noise exposure. Acta Oto-laryngologica, 81(3-6), 337-343.

Janssen, R., Schweitzer, L., \& Jensen, K. F. (1991). Glutamate neurotoxicity in the developing rat cochlea: physiological and morphological approaches. Brain Research, 552, 255-264.

Kil, J., Pierce, C., Tran, H., Gu, R., \& Lynch, E. D. (2007). Ebselen treatment reduces noise induced hearing loss via the mimicry and induction of glutathione peroxidase. Hearing Research, 226(1), 44-51.

Kopke, R. D., Coleman, J. K., Liu, J., Campbell, K., \& Riffenburgh, R. H. (2002). Enhancing Intrinsic Cochlear Stress Defenses to Reduce NoiseInduced Hearing Loss. The Laryngoscope, 112(9), 1515-1532.

Kujawa, S. G. \& Liberman, M. C. (2006). Acceleration of age-related hearing loss by early noise exposure: evidence of a misspent youth. The Journal of Neuroscience: the Official Journal of the Society for Neuroscience, 26, 2115-2123.

Kujawa, S. G. \& Liberman, M. C. (2009). Adding insult to injury: cochlear nerve degeneration after "temporary" noise-induced hearing loss. The Journal of Neuroscience : the Official Journal of the Society for Neuroscience, 29, 14077-14085.

Lamm, K. \& Arnold, W. (1996). Noise-induced cochlear hypoxia is inten- sity dependent, correlates with hearing loss and precedes reduction of cochlear blood flow. Audiology and Neuro-otology, 1, 148-160.

Lamm, K. \& Arnold, W. (1998). The effect of prednisolone and non-steroidal anti-inflammatory agents on the normal and noise-damaged guinea pig inner ear. Hearing Research, 115, 149-161.

Lamm, K., Lamm, C., \& Arnold, W. (1998). Effect of isobaric oxygen versus hyperbaric oxygen on the normal and noise-damaged hypoxic and ischemic guinea pig inner ear. Advances in Oto-Rhino-Laryngology, 54, 59-85.

Le Prell, C. G., Yagi, M., Kawamoto, K., Beyer, L. A., Atkin, G., Raphael, Y., et al. (2004). Chronic excitotoxicity in the guinea pig cochlea induces temporary functional deficits without disrupting otoacoustic emissions. Journal of the Acoustical Society of America, 116(2), 1044-1056.

Le Prell, C. G., Yamashita, D., Minami, S. B., Yamasoba, T., \& Miller, J. M. (2007). Mechanisms of noise-induced hearing loss indicate multiple methods of prevention. Hearing Research, 226(1), 22-43.

Liberman, M. C., \& Kiang, N. Y. (1984). Single-neuron labeling and chronic cochlear pathology. IV. Stereocilia damage and alterations in rateand phase-level functions. Hearing Research, 16, 75-90.

Lynch, E. D., Gu, R., Pierce, C., \& Kil, J. (2004). Ebselen-Mediated Protection From Single and Repeated Noise Exposure in Rat. The Laryngoscope, 114(2), 333-337.

Mulroy, M. J., Henry, W. R., \& McNeil, P. L. (1998). Noise-induced transient microlesions in the cell membranes of auditory hair cells. Hearing Research, 115, 93-100.

Ohinata, Y., Miller, J. M., Altschuler, R. A., \& Schacht, J. (2000). Intense noise induces formation of vasoactive lipid peroxidation products in the cochlea. Brain Research, 878(1), 163-173.

Ohinata, Y., Yamasoba, T., Schacht, J., \& Miller, J. M. (2000). Glutathione limits noise-induced hearing loss. Hearing Research, 146(1), 28-34.

Ohlemiller, K. K., Wright, J. S., \& Dugan, L. L. (1999). Early elevation of cochlear reactive oxygen species following noise exposure. Audiology and Neuro-otology, 4, 229-236.

Puel, J. L., Pujol, R., Ladrech, S., \& Eybalin, M. (1991). a-amino-3-hydroxy5-methyl-4-isoxazole propionic acid electrophysiological and neurotoxic effects in the guinea-pig cochlea. Neuroscience, 45(1), 63-72.

Puel, J. L., Pujol, R., Tribillac, F., Ladrech, S., \& Eybalin, M. (1994). Excitatory amino acid antagonists protect cochlear auditory neurons from excitotoxicity. Journal of Comparative Neurology, 341(2), 241-256.

Ruel, J., Wang, J., Rebillard, G., Eybalin, M., Lloyd, R., Pujol, R., et al. (2007). Physiology, pharmacology and plasticity at the inner hair cell synaptic complex. Hearing Research, 227(1), 19-27.

Seo, J. K., Lim, H. W., Park, H. J., Pak, J. H., \& Chung, J. W. (2013). Changes of Cochlear Nerve Terminals after Temporary Noise-Induced Hearing Loss. Korean Journal of Otorhinolaryngology-Head and Neck Surgery, 56(4), 206-211.

Spoendlin, H. (1971). Primary structural changes in the organ of Corti after acoustic overstimulation. Acta Oto-laryngologica, 71, 166-176.

Wang, J., Ruel, J., Ladrech, S., Bonny, C., van de Water, T. R., \& Puel, J. L. (2007). Inhibition of the c-Jun N-terminal kinase-mediated mitochondrial cell death pathway restores auditory function in sound-exposed animals. Molecular Pharmacology, 71(3), 654-666.

Yamane, H., Nakai, Y., Takayama, M., Iguchi, H., Nakagawa, T., \& Kojima, A. (1995). Appearance of free radicals in the guinea pig inner ear after noise-induced acoustic trauma. European Archives of Oto-rhino-laryngology, 252(8), 504-508.

Yamasoba, T., Nuttall, A. L., Harris, C., Raphael, Y., \& Miller, J. M. (1998). Role of glutathione in protection against noise-induced hearing loss. Brain Research, 784(1), 82-90.

Yamasoba, T., Pourbakht, A., Sakamoto, T., \& Suzuki, M. (2005). Ebselen prevents noise-induced excitotoxicity and temporary threshold shift. Neuroscience Letters, 380(3), 234-238. 